\title{
GDNF wt Allele
}

National Cancer Institute

\section{Source}

National Cancer Institute. GDNF wt Allele. NCI Thesaurus. Code C51505.

Human GDNF wild-type allele is located within 5p13.1-p12 and is approximately $24 \mathrm{~kb}$ in length. This allele, which encodes glial cell line-derived neurotrophic factor protein, is involved in both the survival and differentiation of dopaminergic neurons and in apoptotic motor neuron protection induced by axotomy. Mutantions in the gene produce variant alleles that are associated with Hirschsprung disease. 